\title{
The internationalisation process of Spanish banks: a tale of two times
}

\author{
Clara Cardone-Riportella \\ Associate Professor of Financial Economics and Accounting, Department of \\ Business Administration, Carlos III University of Madrid, Spain \\ Leonardo Cazorla-Papis \\ Associate Professor of Financial Economics and Accounting, Department of \\ Business Administration, University of Almería, Spain
}

\section{Keywords}

Spain, Financial services, Banks, Globalization, Market entry

\section{Abstract}

Attempts to shed light on strategies and international entry modes of financial services firms, providing a framework of the internationalisation process in one specific industry. This is based upon the analysis of four case studies of Spanish banks entering the Latin American markets at two different stages - before and after the 1990 s - to see how

internationalisation strategies of financial services have evolved over time. Shows that, in accordance with the perceived market risk and the commitment of resources involved, firms may opt to enter a foreign market in a gradual (lineal) process or in a more opportunistic (contingent) way. The foreign direct investment decision vis-à-vis the resources and risks involved in the operation has been evolving through time, industry and country of destination.

\section{This manuscript has benefited from the helpful comments of two anonymous referees and the Editors. The authors acknowledge the financial support of the Spanish Ministry of Education and Culture, Dirección General de Enseñanza Superior, projects PB 97-0084 DGES and PB 97-0089 DGES.}

\section{Introduction}

Recent decades have seen considerable growth of the services sector in the economies of both industrialised and developing countries. This growth has been accompanied by the expansion of international capital flows originating in the services sector, especially financial services. In this context, the intensification of internationalisation processes in banking is one of the most important developments in recent economic history and the most striking example of the degree of globalisation, internationalisation and integration of financial markets that now exists world-wide.

This process of internationalisation has not passed Spanish banks by. The growing rivalry and the pressure on profit margins in the sector, direct consequences of economic integration in Europe, together with the emergence of new business opportunities in foreign markets, has prompted a significant part of Spanish banking to develop new competitive growth strategies. In this way, alongside processes of merger, acquisition and alliance in the domestic sphere, the main Spanish banks have developed an active strategy of internationalisation with a view to acquiring stakes in foreign markets where there are new business opportunities. The advantages of localisation that now exist in many Latin American countries (the potential consumer market, the low level of banking services and competition in the area, the lack of a strong "psychological barrier", the growing liberalisation of the financial sector in these countries, etc.) have persuaded the Spanish banks to significantly augment their presence on that continent.

The object of the present study is twofold:
1 to analyse from a theoretical standpoint the modes of entry used by Spanish banks in the internationalisation process; and

2 to analyse from a dynamic and temporal standpoint the nature of the internationalisation process and the modes of entry used by the banks in their geographic expansion in Latin America.

As it could be inferred from the title of the paper, there are two periods which undoubtedly are relevant in the comprehension of the paper - the periods before and after 1990. From 1990 the investment undertaken by the Spanish banks reaches a significant volume. The economic stability in most of the countries and the start of economic integration are the main reasons that led the European countries, particularly Spain, to look to these new markets because of their importance in the achieving of larger market shares.

In order to address these objects, we will review the chief theoretical findings relating to the phenomenon of bank internationalisation, focusing on the nature of the modes of entry used. In this way we seek to determine what characteristics of the banking business influence decisions of this kind. Then we will analyse the behaviour patterns followed by the four Spanish groups with the largest presence in Latin America, namely Banco Bilbao Vizcaya, Banco Exterior de España, Banco de Santander and Banco Central Hispano prior to their merger, before presenting our conclusions.

\section{Internationalisation process and modes of expansion of service companies}

The internationalisation of the firms has been an increasingly important research 
area among international scholars, particularly studies related to the internationalisation of service companies, where there have been many attempts to apply theories designed for industrial companies to services. Organisations in the financial sector have, historically, been very active in the internationalisation process and the degree of international activity makes them a fruitful area for research. There are quantitative and qualitative reasons, which allow us to justify the importance of the international process undertaken by the financial companies in the last few years. Czinkota and Ronkainen (1997), applying Delphi technique to a group of politicians from the international business world, tried to do an evaluation of the changes that will occur in the international business environment in the next 25 years. Their main results were the following:

1 geography in international business: "global economic growth will be fuelled to a great extent by emerging markets of the Asia-Pacific and Latin America"; and

2 in relation to the sector, "the largest transformations are anticipated in services industries", and companies involved in the financial sector will experience a major international expansion process.

From the quantitative point of view (Cardone et al., 2000), it could be said that the activities linked to service-sector companies, as well as FDI made by service-sector companies, have significantly grown since the late 1980s.

Nowadays, the service sector employs 70 per cent of the population in the OECD countries (Edvardsson and Modell, 1996).

When we speak of internationalisation of banking, we refer to two separate but closely related issues. First, in a broad sense, the term may be understood in terms of both activity and physical presence abroad (Aliber, 1984). The first aspect refers to the export and import of banking services between residents and non-residents, the carrying out of transactions in foreign currency from the local country, and the role that the banks play in international capital flows. The second aspect refers to the internationalisation strategy followed by companies of this kind, with particular reference to the nature of the factors that determine the process, the modes of entry used and the choice of country or countries for location of the activity.

Looking more closely at the second of these aspects, the literature ought to answer three basic questions: why, how and where do banks expand their activity abroad? In the specific context of the internationalisation of banking, researchers have sought with varying success to adapt the basic assumptions of the predominant theoretical approaches to the context of internationalisation of industrial companies, and in particular approaches relating to direct investment and to the "conventional" (meaning industrial) multinational company (Grubel, 1977; Gray and Gray, 1981; Giddy, 1986; Casson, 1990; Jones, 1990; Goldberg and Johnson, 1990; Heinkel and Levi, 1992; Mahajan et al., 1996; Williams, 1997).

Leaving aside certain differences, most of these researchers suggest that the factors determining the phenomenon of internationalisation in the context of nonfinancial companies (conventional MCs) are equally applicable to similar processes undertaken by banks. In this connection it can be argued that both kinds of company seek to exploit certain advantages for themselves in foreign countries ("monopolistic advantage approach" and "organisational capacities approach"). To the extent that these advantages are underpinned by specific intangible assets, the company will find it more profitable to internalise such advantages within its own organisation and hierarchy rather than externalising them in the marketplace by contracting out to third companies, in view of certain imperfections associated with high transaction costs ("transaction costs approach" or "internalisation theory"). And finally, advantages of location will determine the placing of the business activity in a specific geographical area.

However, on the basis of the significant differences between the two types of enterprise, we can point to the existence of specific features characterising the process of internationalisation of banking, which features particularly influence the design of the internationalisation strategy and the modes of entry used. According to Rugman (1981), these differences fall into three groups of variables:

1 Banks are service enterprises, whereas "conventional" multinationals typically produce and operate goods.

2 Banks provide services based on specialised information through intensive use of the work factor. "Conventional" multinationals, on the other hand, use not only work but capital and technology in their production function.

3 The sole capacity of banks is to act as financial middlemen.

We may therefore conclude that banks are active agents in the gathering, processing 
and utilisation of specialised information. The control and application of information is the central element of banking activity, as financial mediation is a process in which the bank centralises information used by lenders and borrowers. This special nature of the financial mediation function, and its particular configuration at an international level, are the two most important differentiating factors.

In examining internationalisation for a specific sector, Rugman (1979) suggests that the first factors to consider are the differentiating characteristics of that sector. Following Casson (1990), then, an analysis of the internationalisation of banking should focus on the internationalisation of service enterprises in general. Compared to tangible goods, services present a number of special features which can influence the choice of mode of entry and the nature of the chosen internationalisation process. In this connection we would highlight the following differentiating features of services:

1 the degree of intangibility;

2 the simultaneity of production and consumption; and

3 the degree of interaction between consumer and producer (Vandermerwe and Chadwick, 1989; Buckley et al., 1991).

Different types of service can be identified with respect to these variables. According to Vandermerwe and Chadwick (1989), we may distinguish between services "in the strict sense", "tangibly-based" services, and "complementary" services. The first of these are intangible services not tied to material goods, in which production and consumption are simultaneous. On the other hand, tangibly-based and complementary services are those that have a greater or lesser basis in material goods. Lovelock and Yip (1996) distinguish between services "based on processes involving customers", services "based on processes involving material goods" and services "based on information". In this last case the key factor is the company's capacity to collect, process, interpret and transmit information.

Moreover, the degree of interaction between customer and producer is normally high, and the quality and capacity of the company's personnel thus becomes a key factor in the ability to deliver the service.

A company enjoying certain advantages of its own and deciding to exploit these abroad must choose one of three generic strategic options: export, foreign direct investment (FDI) or licensing agreements. In the first two cases the company internalises its own advantages within its organisation, siting production either in the country of origin export - or abroad. In the third case the company externalises production - in other words, it contracts foreign companies to exploit all or part of its home advantages. Both FDI and export can be undertaken alone or in combination with other companies, giving rise to new hybrid entry formulas based on collaboration - alliances, cooperation agreements, joint ventures, etc. Also, FDI can assume various different modes depending on the strategy that is determined - creation of a new enterprise or acquisition of existing enterprises - and the degree of participation/control possessed by the investor. As a result, any company, depending on its objectives, degree of control, level of resources and capabilities, or the risk that it is prepared to accept, may choose from a wide range of alternative modes of entry.

In the context of internationalisation of service enterprises, export is probably the best strategy for services underpinned by material goods where there is also little interaction between producer and consumer. Contractual forms such as licences, franchises or joint ventures can be used where the services, although not entirely "underpinned" by material goods, depend on these for delivery, especially when the degree of customer/producer interaction is high. And finally, FDI is the preferred strategy for services where there is very high producer/ customer interaction and proximity to the customer is a key factor for success (Vandermerwe and Chadwick, 1989) (see Table I).

The differentiating features of services can also influence the nature of the internationalisation process over time. In this respect, a large part of the literature focuses on a dynamic and time-based approach to the analysis of the process. Important in this context is the progress achieved by the "gradual phases of development school" (Johanson and Wiedersheim-Paul, 1975; Johanson and Vahlne, 1977; 1990). This approach consists of viewing business internationalisation as a gradual, evolutionary process through which the enterprise builds up increasing levels of international commitment as it acquires more experience and know-how and commits more resources abroad. The model describes the path that would be followed by an enterprise as it internationalises, and it identifies four time-based phases:

Phase 1: the enterprise exports sporadically;

Phase 2: exports are stabilised through independent agents;

Phase 3: the enterprise opens up commercial subsidiaries abroad; and 
Phase 4: the enterprise opens up production subsidiaries abroad.

The gradual, cumulative process described derives from a learning effect whereby the enterprise perceives less risk as it gains experience in operating in international markets. The gradual nature of the process is further perceptible in growing commitment of resources to more complex organisational formulas entailing an increasing degree of control over operations[1].

\section{Gradual model vs contingent model}

Basically, most researchers have been trying to answer the question about why banks expand their activities among different markets. The present work tries to answer how banks expand their activities among different markets. Papers by Engwall and Wallenstål (1988), Hellman (1996), Majkgård and Sharma (1998) and Sharma and Johanson (1987) studied the internationalisation of Nordic financial service companies all over the world, meanwhile Cardone et al. (2000) examines the internationalisation patterns followed by Finnish and Spanish financial services companies - banks and insurance entities - to find out whether they are more influenced by "customer-following" and/or "market-seeking" approaches[2].

The "gradual model", like other theories that attempt to explain the various aspects of internationalisation, has likewise been applied in the context of industrial enterprises. On this point the question arises of whether the differentiating features of services may also influence the nature of the chosen internationalisation process in dynamic terms. In this respect Enderwick (1989) suggests that the incremental evolutionary hypothesis for the process would not hold for services where production and consumption are simultaneous.

In these cases enterprises have no choice from the outset but to locate production abroad, by means of either FDI or contractual formulas such as licensing agreements and thus without going through an early export phase. Contrary to this, some researchers hold that the process is an incremental one.

\section{$\overline{\text { Table I }}$}

Modes of entry and characteristics of services

\begin{tabular}{lll}
\hline & Producer/customer interaction & Tangibility \\
\hline Export & Low & High \\
Alliances (licences, joint ventures) & Medium-high & Medium \\
FDI & High & Low
\end{tabular}

Source: compiled by the authors from Vandermerwe and Chadwick (1989)
Thus, some service enterprises - services "in the strict sense" - internationalise gradually, penetrating a foreign market through lowrisk contractual formulas, or by setting up joint ventures with local partners (Buckley et al., 1991). This means that depending on the "perceived risk" and the "level of commitment of resources abroad", service enterprises have internationalised in line with two distinct behaviour patterns or models - namely, either according to a "gradual or linear model" or according to an "opportunistic or contingent model" (Cardone and Cazorla, 1998) (see Figure 1). Where the perceived level of risk is low, whether by reason of scant market competition or the lack of major changes in the regulation of the sector concerned, there are incentives to commit more resources. Conversely, where the perceived level of risk is high - that is, in highly competitive markets with constant changes in regulation - there are no such incentives, at least in an initial approach to the market.

When the mode of entry is "gradual", internationalisation takes place in two phases:

1 An exploratory phase where the objective is to gain the requisite experience and know-how. In this phase the enterprise resorts to low-cost, low-risk modes of entry such as opening up branch offices and entering into cooperation agreements with local partners.

2 In the second phase, with the experience gained in the first phase, the enterprise augments its physical presence abroad through more complex organisational formulas entailing a greater degree of control.

These were basically the modes of entry utilised by industrial enterprises in the 1970s, which judged investments to be viable as long as autonomous profitability exceeded the costs of financing (current net value and internal rate of return) (see Table II).

In the "opportunistic or contingent model" penetration of foreign markets is a single event, achieved either through mergers with

\section{$\overline{\text { Figure } 1}$}

Entry mode strategies in foreign markets

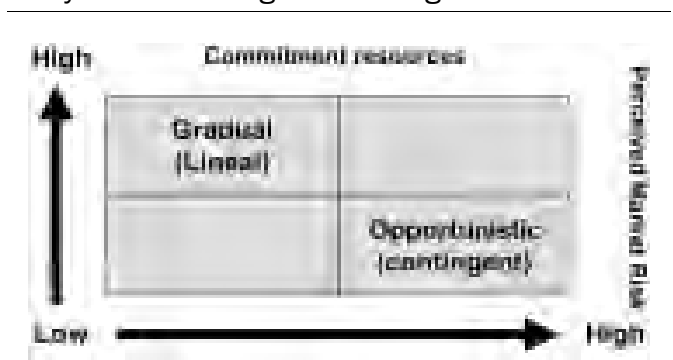


Table II

Characteristics of the different entry modes in services

\begin{tabular}{lll}
\hline Mode characteristics & Gradual & Opportunistic \\
\hline Approach & Lineal & Contingent \\
Usual forms & Holding, representative office or joint & Takeovers, M\&A \\
& ventures and cooperation agreements & \\
Perceived risk & Medium/high & Usually low \\
Commitment of resources & Gradual & High \\
Competition & Low/medium & High \\
Market regulation & Changing slowly & Sudden change \\
Assessment & NPV/IRR & NPV/option theory \\
Time & Mainly up to the 1970s & In the 1980s and 1990s \\
Industry & Manufacturing & Services (e.g. telecommunications, \\
& & insurance, banking, hotel industry) \\
\hline
\end{tabular}

enterprises having a consolidated position in the target market, or through the total or partial acquisition of existing companies. In this case the objective is to take advantage of major opportunities in that market as swiftly as possible. With the stabilisation and political/economic freeing-up of certain markets over the last 20 years, it has been mainly service enterprises, which have taken up positions there. If the enterprise first acquires a minority stake and builds this up over time, investors are able to analyse potential future profitability without having to commit themselves beforehand. This type of investment has been encouraged by socalled real options.

In front of the valuation of investment projects through the use of the net present value (where the expected actual value of the cash flows should be greater than its acquisition and installation costs, or at least, being an amount equal to the value the investment option), there is a theoretical approach grounded on "real options" (Mascareñas, 2000).

This approach is based on the fact that the investment decision could be modified because of the following items:

- irreversibility;

- uncertainty; and

- decisor's working capital.

Different types of "real options" try to explain the internationalisation process, for instance:

- the option to defer;

- the option to modify the scale of the operations;

- the time available to create options (stage investment); and

- the option to change.

Among these types of options, the growing up and abandonment options may be applied to the expansion process in the financial services companies (Myers and Majd, 1990; Chung and Charoenwong, 1991; Kester, 1993).
If the market conditions are not those that we expected then the decision could be to decline or increase the investment through the acquisition of the market set.

\section{The entry modes of Spanish banks in Latin America}

Services have become the major sector in the Spanish economy. Thus, in 1996, services represented 59.4 per cent of GDP. Direct overseas financial service investment, on its part, has grown enormously over the last decade, increasing from 38 per cent in 1980 to touching 60 per cent in 1990. In 1997, capital export as carried out by Spanish banks represented 56 per cent of total direct investment. Just three banks were responsible for 42.7 per cent of this investment figure. Banco de Santander (BS) had invested 25.5 per cent, 13.8 per cent belonged to Banco Bilbao Vizcaya (BBV) and 3.4 per cent to Banco Central Hispano $(\mathrm{BCH})$.

In the 1990s, Latin America became the new focus for the flows of Spanish direct investments, especially those that have their origins and purposes in the banking and financial sector (Table III).

In 1987, the Spanish bank sector could be described as follows: seven banks held 20.5 per cent of the banking sector's total assets. Of this 20.5 per cent, Banco Central had 3.8 per cent; Banco Vizcaya, 3.3 per cent; Banco Nacional de Crédito, 3 per cent; Bilbao, Hispano and Santander each had 2.9 per cent; and, finally, Banco Popular held 1.7 per cent. At the end of the 1980s, and the beginning of the 1990s, a merger process commenced with a view to the single market. Thus, in 1994 the commencing date of the bank expansion process in the Latin America market - the Spanish bank sector map was as follows: 53.8 per cent of total bank assets were in the hands of only five banks (Santander, 15.1 per cent; Argentaria, 11.9 per cent; BBV, 10.6 per 
cent; Popular, 3.2 per cent; and Banco Central Hispano, 1.3 per cent).

With respect to the Latin American market, it covers an area of over 20 million $\mathrm{km}^{2}$ (15.4 per cent of the world's area). Brazil occupies 40 per cent and represents the same percentage of the GDP. Its population represents 8.4 per cent of the world's total. The percentage distribution of FDI flows to this market during the last decade was 30 per cent of the total world FDI (World Development Report, 1997) with Brazil and Argentina being the main target countries. With regard to the bank sector, in December 1994, 82.4 per cent of bank assets, 83.4 per cent of the overall loans and 80.5 per cent of overall deposits in the region belonged to 20 banks, which were mainly concentrated in four countries: Brazil, Mexico, Argentina and Chile (see Table IV).

This study will centre on analysing the different stages in the internationalisation process as followed by the four main Spanish banks - Banco de Santander, Banco Bilbao Vizcaya, Banco Central Hispano and Banco Exterior (of the Argentaria group) - in the Latin American market until 1998. In 1999, two important mergers took place in the Spanish bank

\section{$\overline{\text { Table III }}$}

Spanish foreign direct investment

\begin{tabular}{|c|c|c|c|c|}
\hline \multirow[b]{2}{*}{ Year } & \multirow[b]{2}{*}{$\begin{array}{l}\text { Total (thousands } \\
\text { of millions pesetas) }\end{array}$} & \multicolumn{3}{|c|}{ In Latin America market } \\
\hline & & $\begin{array}{l}\text { Total (thousands } \\
\text { of millions pesetas) }\end{array}$ & Percentage & $\begin{array}{l}\text { Financial sector } \\
\text { (per cent) }\end{array}$ \\
\hline 1985-1989 & 721.1 & 76.86 & 10.65 & 32.00 \\
\hline 1990 & $4,654.8$ & 41.09 & 9.03 & 54.28 \\
\hline 1991 & 633.2 & 82.9 & 13.1 & 14.87 \\
\hline 1992 & 518.0 & 23.3 & 5.5 & 47.07 \\
\hline 1993 & 442.8 & 67.1 & 15.2 & 71.10 \\
\hline 1994 & $1,020.0$ & 453.8 & 44.5 & 26.67 \\
\hline 1995 & 948.3 & 197.4 & 20.8 & 68.29 \\
\hline 1996 & $1,233.7$ & 525.8 & 42.6 & 73.00 \\
\hline 1997 & $1,957.4$ & $1,059.1$ & 54.1 & 72.96 \\
\hline
\end{tabular}

Source: Registro de Inversiones Españolas en el Exterior and CEPAL (2000) sector. First, Banco Central Hispano merged with Banco de Santander. Second, some months later, Banco Bilbao Vizcaya merged with Argentaria.

Three types of sources have been used:

1 Salomon Smith Barney: Bank Reference Guides of Argentina, Brazil, Chile, Colombia, Mexico, Peru and Venezuela (Salomon Smith Barney, 1997); and Latin American Equity Research: Latin America - Banks, Latin American Bank Annual (Salomon Smith Barney, 1998). Annually, this publication gives information regarding the largest banks in each of the Latin American countries, including financial statistics - asset, loan and deposit market share, as a percentage of the total system.

2 The banks' annual reports, basically made up of information coming from reviews about the foreign investment in recent years. This information is useful for validating the information coming from the financial newspapers.

3 National (Cinco Dias and Revista Tribuna) and international (The Economist) newspaper publications.

Why and when did Spanish banks commence the internationalisation process towards Latin America? Furthermore, what characterised those financial markets during the years when the Spanish banking sector expansion process took place? In the 1990s, conditions both in the Spanish and European markets and the Latin American market were as follows:

1 Spanish and European markets:

- The European integration process brought as a consequence - apart from an increase in intra-community trade and the free movement of capital - a loss of character of European markets. This re-dimensioning of the market encouraged Spanish banks to look at other markets, specifically Latin America.

\section{$\overline{\text { Table IV }}$}

Ranking and market shares of the 20 largest banks of the region

\begin{tabular}{|c|c|c|c|c|c|c|c|c|c|c|c|c|}
\hline \multirow[b]{3}{*}{ Country } & \multicolumn{4}{|c|}{ Assets } & \multicolumn{4}{|c|}{ Loans } & \multicolumn{4}{|c|}{ Deposits } \\
\hline & \multicolumn{2}{|c|}{ December 1997} & \multicolumn{2}{|c|}{ December 1994} & \multicolumn{2}{|c|}{ December 1997} & \multicolumn{2}{|c|}{ December 1994} & \multicolumn{2}{|c|}{ December 1997} & \multicolumn{2}{|c|}{ December 1994} \\
\hline & $\%$ & No. of banks & $\%$ & No. of banks & $\%$ & No. of banks & $\%$ & No. of banks & $\%$ & No. of banks & $\%$ & No. of banks \\
\hline Brazil & 47.6 & 8 & 39.9 & 8 & 41.0 & 6 & 32.0 & 5 & 35.6 & 6 & 37.7 & 8 \\
\hline Mexico & 15.1 & 4 & 27.1 & 5 & 22.3 & 6 & 34.2 & 6 & 22.2 & 5 & 27.4 & 5 \\
\hline Argentina & 8.6 & 4 & 6.7 & 3 & 8.5 & 4 & 10.0 & 5 & 10.9 & 4 & 4.9 & 2 \\
\hline Chile & 7.7 & 4 & 8.7 & 4 & 7.4 & 4 & 7.2 & 4 & 9.1 & 5 & 8.9 & 4 \\
\hline Venezuela & & & & & & & & & & & 1.6 & 1 \\
\hline Total & 79.0 & 20 & 82.4 & 20 & 79.2 & 20 & 83.4 & 20 & 77.8 & 20 & 80.5 & 20 \\
\hline
\end{tabular}

Source: Salomon Smith Barney (1998) 
- In parallel fashion, financial markets were reaching the heights of maturity bringing with it an increase in competition accompanied by a heavy reduction in utility margins reduction in interest rates - and, consequently, in profitability.

- Finally, the increasingly more significant foreign participation in the capital of Spanish banks suggests that the results of these companies are not solely dependent on the domestic market's opportunities[3].

2 Latin American market:

- For its part, Latin America displayed good investment opportunities to the extent that most of the countries in the region were reaching higher levels of economic soundness at the beginning of this decade as a consequence of political stability.

- Latin America was not alien to the advantages of economic integrations and economic integration processes commenced in this decade. The most significant were the agreements signed between Canada, the USA and Mexico (NAFTA), and that signed between Argentina, Brazil, Paraguay and Uruguay (MERCOSUR).

- Low market personal banking services indices and the increasingly greater acceptance of new products increased profit potential[4,5] (Table V).

- The existence of a common language and similar idiosyncrasies has made the region a natural market.

- At the same time, a generalised privatisation and liberalisation process commenced, particularly in the financial sector (Table VI).

We shall discuss the different steps as taken by the banks analysed in the following sections[6].

\begin{tabular}{lccc}
\hline $\begin{array}{l}\text { Table V } \\
\text { Use of banking services in selected countries in Latin America, }\end{array}$ & 1992 \\
\hline Country & Deposit accounts & Current accounts & Credit cards \\
\hline USA & 2.2 & 1.3 & 1.0 \\
Argentina & 0.6 & 0.6 & 0.1 \\
Brazil & 2.9 & 0.3 & 1.4 \\
Colombia & 1.4 & 0.2 & 0.2 \\
Venezuela & 1.9 & 0.4 & 0.4 \\
Mexico & 1.2 & 0.8 & 0.2 \\
Chile & 3.1 & 0.4 & 0.2
\end{tabular}

Notes: All figures are units per person for people over 18 years old. In Spain, 9.9 out of ten people have some kind of banking relation. In Latin America this number is only four. Source: McKinley Global Institute (1994)

\section{The Latin American experience of Banco de Santander}

The Banco de Santander (BS) started its internationalisation process about 50 years ago (the first investment was in Mexico in 1951). Nowadays it is present in 13 Latin American countries. Its internationalisation process in Latin America was carried out in two well-defined stages. A first stage can be traced prior to the 1990s when it only set up representative offices in five countries (Argentina, Brazil, Chile, Mexico and Venezuela) while immediately signing agreements with banks in Puerto Rico. The second stage, characterised by the partial and/or total purchases of banks without a significant market share - second tier banks or financial institutions commenced in the 1990s. Basically, the adopted strategy involved the following points:

- The taking of majority holdings when the local partner allowed for it, partial purchases ranging from 37.06 per cent to 98 per cent and full purchases.

- The development of a regional franchise of financial services in the whole area, wherein all new offices share the name and the colours of BS. It allowed for its culture to be spread very quickly.

- The confidence inspired by the corporate image allowed for the application of banking models, which have been previously applied successfully in local markets.

- BS keeps control of all its Latin American banks, which maintain a policy of universal banking practices (see Table AI in the Appendix).

\section{The Latin American experience of Banco Bilbao Vizcaya}

Banco Bilbao Vizcaya (BBV) is nowadays present in 11 Latin American countries and its first investments were carried out at the beginning of the 1980s (in Panama and Puerto Rico). In 1991 it started a new strategy, pursuing the BBV group's positioning in emerging markets like Argentina, Colombia, Mexico, Peru, and Uruguay. During this stage, the bases for the internationalisation process were the following:

- Control of the local entity, making the minimum possible investments and total purchases - partial purchases ranged from 3.9 per cent to 71.75 per cent. Leading entities were chosen among targeted countries as they were considered capable of providing knowledge of the market and institutional models.

- Spanish employees helped domestic Latin American managers. 
$\overline{\text { Table VI }}$

Regulation of FDI in different Latin American countries

\begin{tabular}{|c|c|c|c|c|c|}
\hline \multicolumn{3}{|c|}{1988} & \multicolumn{3}{|c|}{1995} \\
\hline \multirow[b]{2}{*}{ Entry $^{a}$} & \multicolumn{2}{|c|}{ Exit $^{\mathrm{b}}$ : repatriation of } & \multirow[b]{2}{*}{ Entry $^{a}$} & \multicolumn{2}{|c|}{ Exit ${ }^{\text {b }}$ repatriation of } \\
\hline & Income & Capital & & Income & Capital \\
\hline Free entry & & & Free entry & & \\
\hline No country & & & $\begin{array}{l}\text { Argentina, Brazil, } \\
\text { Costa Rica, Ecuador, } \\
\text { Mexico and Peru }\end{array}$ & Free & Free \\
\hline Relatively free & & & Relatively free & & \\
\hline Argentina & Restricted & After 3 years & Chile & Free & After 1 year \\
\hline Chile & Free & After 5 years & Venezuela & $\begin{array}{l}\text { Some } \\
\text { restrictions }\end{array}$ & $\begin{array}{l}\text { Some } \\
\text { restrictions }\end{array}$ \\
\hline Costa Rica & $\begin{array}{l}\text { Some } \\
\text { restrictions }\end{array}$ & $\begin{array}{l}\text { Some } \\
\text { restrictions }\end{array}$ & & & \\
\hline Venezuela & $\begin{array}{l}\text { Some } \\
\text { restrictions }\end{array}$ & $\begin{array}{l}\text { Some } \\
\text { restrictions }\end{array}$ & & & \\
\hline \multicolumn{6}{|l|}{ Special classes } \\
\hline Mexico & Free & Free & & & \\
\hline \multicolumn{3}{|l|}{ Authorised funds } & \multicolumn{3}{|l|}{ Authorised funds } \\
\hline Brazil & Free & $\begin{array}{l}\text { Some } \\
\text { restrictions }\end{array}$ & Colombia & Free & Free \\
\hline \multicolumn{6}{|l|}{ Closed } \\
\hline Colombia & $\begin{array}{l}\text { Some } \\
\text { restrictions }\end{array}$ & Free & & & \\
\hline Peru & Restricted & Restricted & & & \\
\hline \multicolumn{6}{|c|}{$\begin{array}{l}\text { Notes: } \\
\text { a Free entry: no restrictions at all; relatively free: some restrictions to assure repatriation rights; special } \\
\text { classes: FDI restricted to special classes; authorised funds: only approved foreign investors; closed: FDI very } \\
\text { restricted, only for non-residents. } \\
\text { b Repatriation of income: dividends, interest, income; repatriation of capital: initial capital invested; } \\
\text { free: repatriation done frequently; some restrictions: requires permission of authorities }\end{array}$} \\
\hline Sources: World In & ment Repol & 96); Ruesga & Bichara (1988) & & \\
\hline
\end{tabular}

- Regarding the commercial name of the bank, the strategy initially used was to keep the name of the local partners as a way of using their experience and domination of local markets.

- Universal banking practices were widely adopted (see Table AII in the Appendix).

\section{The Latin American experience of Banco Central Hispano}

Today, Banco Central Hispano (BCH) is present in 15 countries and its first investment was carried out in 1973. BCH's internationalisation process may be described in two stages. First, in the period prior to $1990, \mathrm{BCH}$ only set up representative offices. Then, in a second stage, beginning in 1994, the predominant strategy was to make partial acquisitions ranging from 0.03 per cent to 90.0 per cent, although some new representative offices were opened in Uruguay and the Dominican Republic.

BCH's investment strategy may be summed up as one of entry into the Latin
American market through a local bank. In 1993, BCH had a branch in Chile, which it integrated into Banco O'Higgins (local), thus giving rise to the holding company O'Higgins Central-Hispano (OHCH). In Argentina, Uruguay, Paraguay and Peru, it operates through this O'Higgins Central-Hispano Holding Company. In Mexico, it has a 10 per cent stake at Banco International (BITAL). Its strategic features are:

- Search for business opportunities in potential growth entities.

- Taking advantage of existing office networks.

- Principle of non-intervention in management. This is an essential point that differentiates it (see Table AIII in the Appendix).

\section{The Latin American experience of Argentaria}

Banco Exterior (BEX) formed part of the largest state bank holding company in Spain, Argentaria. BEX entered Latin America as a 
state-owned bank, which was focused on financing foreign trade transactions between the region's countries and Spain, i.e. it was devoted to service banking. In the 1980s, as a likely consequence of the Latin American debt crisis, it commenced a divestiture process, which led to the unification of its subsidiaries in Argentina, Brazil, Chile and Paraguay, and to keep a stake of the 19.9 per cent of Extebandes in Bolivia, Colombia, Ecuador, Peru and Venezuela. In 1996 it only had one representative office in Colombia, and a branch in Brazil (Warner, 1998).

According to the analysis made, two different stages in the internationalisation of Spanish banks in the Latin American market can be clearly observed.

\section{Stage I: before 1990}

Gradual: 1) Representative Office Branch $\Rightarrow 2) \mathrm{JV} / \mathrm{CA} \Rightarrow 3$ ) FDI $(\mathrm{M} \& \mathrm{~A}) \Rightarrow$

where $\mathrm{JV} / \mathrm{CA}=$ joint ventures and cooperation agreements. During this stage the European market re-dimensioning process had not yet commenced and conditions in the Spanish market were highly profitable.

Uncertainty and risk predominated in the Latin American market and, therefore, banks entered timidly, investing the minimum. Banks entered whilst committing low resources in view of a lack of knowledge of the market and the level of risk existing in the economies of the region's countries. Thus the stage is identified with the application of a gradual (linear) strategy where commencement is made with the setting up of representation offices, followed by the signing of cooperation agreements and joint ventures and subsequently partial or total company FDI were undertaken.

Countries like Puerto Rico and Panama were the exception as an investment target point on the part of Spanish banks during this first stage. Puerto Rico was an intermediate destination allowing for subsequent access to the US market. On its part, Puerto Rico offered the advantages typical of a tax haven.

During this stage, financial services sector followed an internationalisation process that was broadly similar to that of manufacturing industry. The type of international banking activity conducted was wholesale banking and service banking. The main Spanish banks present in that process were $\mathrm{BS}, \mathrm{BCH}$ and BEX.

\section{Stage II: after 1990}

Opportunistic: 1) JV/CA $\Rightarrow$ 2) FDI (M\&A)

where $\mathrm{JV} / \mathrm{CA}$ = joint ventures and cooperation agreements. During this stage, with the European market re-dimensioning process now in progress, and in view of the lesser risk and uncertainty on the Latin American market, banks - those which had already entered in the first stage and those which had not - commenced a heavy investment process through mergers and total and partial acquisitions (M\&A).

During this stage banks use certain advantages such as:

1 the existence of a situation similar to that which existed in Spain somewhat more than a decade ago;

2 the existence of a financial market with a low degree of personal banking service together with a shortfall of bank products;

3 wide margins as a consequence of little or nil remunerated liabilities and high profit assets; and

4 low technological and organisational levels.

The stage is identified with the application of an opportunistic strategy where postponing entry into the market may mean losing the opportunity because other entities have already found their place, thus increasing competition.

The international banking activity, which characterised this stage, was retail banking which - as discussed earlier - required direct investment to be made in the host country. During this stage, financial service internationalisation preceded industrial activity internationalisation. To this effect, a two-directional process of confidence[7] was generated in which financial firms chose markets they perceived as having low risk, a strategy followed by industrial companies in the "follow the leader" fashion.

In Figure 2 we show the characteristics of the internationalisation of companies according to risk as perceived by them and the resources they are prepared to commit. When the risk as perceived is high (stage I), companies risk very few resources. As the risk perceived diminishes, companies which already knew the market continue a gradual investment process, whilst companies who were not present, take advantage of the opportunities and enter the market in an opportunist fashion (Figure 2).

This analysis shows that that Spanish banks have responded to an internationalisation process in two distinct ways, according to whether before or after 1990, when major changes in the Spanish and 


\section{$\overline{\text { Figure 2 }}$}

The Internationalisation process of the main Spanish banks in Latin America

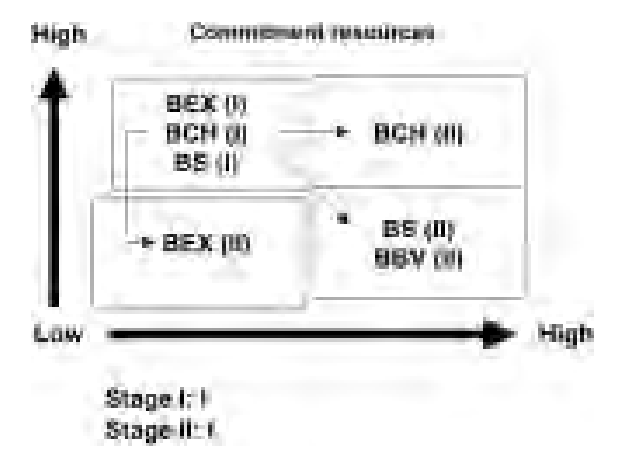

European markets and the Latin American market occurred.

\section{Summary and concluding remarks}

The classical theory of company internationalisation does not always match the internationalisation of service companies. Given the internationalisation of services is relatively recent there is a need to consider how existing theories many help in understanding this process. Services in general display special characteristics differentiating them from goods, but, in addition, the speed with which information circulates, the greater competition existing on markets, the liberalisation of financial markets lead, amongst other reasons, to strategies as used by service companies differing from those applied by goods companies.

Entry strategies can be divided into two categories:

1 gradual, incremental, step-by-step trial investments; and

2 opportunistic, contingent, full-scale acquisition or greenfield investment, in accordance with the risks and resources involved in the foreign market.

This paper has analysed the internationalisation process towards the Latin American market of the four major Spanish banks by focusing on the firms' historical process, at two different times, to see how they have been using opposite but complementary processes. We conclude that Spanish banks have responded to an internationalisation process belonging to two well differentiated times, according to whether before or after 1990, when major changes in the Spanish and European markets and the Latin American market occurred.

During the first stage - before 1990 - banks entered whilst committing low resources in view of a lack of knowledge of the market and the level of risk existing in the economies of the region's countries. Thus the stage is identified with the application of a gradual (linear) strategy where commencement is made with the setting up of representation offices, followed by the signing of cooperation agreements and joint ventures and only subsequently was partial or total company FDI undertaken.

During the second stage - beginning in the 1990s - banks have used certain advantages such as:

- the existence of a situation similar to that which existed in Spain somewhat more than a decade ago;

- the existence of a financial market with a low degree of personal banking service together with a shortfall of bank products;

- wide margins as a consequence of little or nil remunerated liabilities and high profit assets; and

- low levels of technological and organisational development.

The stage is identified with the application of an opportunistic strategy where postponing entry into the market may mean losing the opportunity because other entities have already found their place.

We propose a framework of entry modes in foreign markets which is not static but, rather, dynamic and evolving over time. A firm's decision to enter a foreign market will depend mainly on two initial factors:

1 perceived risk; and

2 resources (human, capital, organisation, etc.).

The companies may choose to enter foreign markets in a gradual (linear) way, where firms commit more resources as they learn along the way and risks are perceived to be lower. On the other hand, the firm may use a more opportunistic or contingent approach if market risk is lower or competition more severe. This strategy may evolve over time as risk and competition keep changing.

\section{Notes}

1 The gradual nature of the process described also has consequences for the choice of target overseas markets. Thus, seeking to incur the least possible risk, the company will initially direct its international activity to those geographic markets separated by the smallest "distance" or "psychological barrier", i.e. those markets that are most culturally akin. The terms "distance" and "psychological barrier" embrace an entire group of factors relating to language, educational level, business habits, market climate, the institutional framework or the degree of industrial development, all affecting the levels 
of risk perceived by the company (see, for example, Luostarinen, 1970; 1979;

Wiedersheim-Paul, 1972; Johanson and Wiedersheim-Paul, 1975; Johanson and Vahlne, 1977; 1990).

2 Some authors, such as Engwall and Wallenstål (1988), Terpstra and Yu (1988), Erramilli (1990), Erramilli and Rao (1990) and Hellman (1996), have identified two large groups of conditions which determine the entry forms and the gold country of the service-sector firms in their internationalisation process. The first group, "market seeking", refers to the case where a service firm enters foreign markets primarily to access new markets and opportunities. Traditional economic theories propose that firms strive to maximise their profits. To attain this objective in their internationalisation process, they would choose the most attractive markets, in terms of economic potential, first. When these markets become saturated, they will enter less attractive ones. The second group, "client following”, is exclusive and very characteristic of the service sector, in its occurrence and importance (for instance, many American advertising agencies and banks follow their US clients to overseas markets). The internationalisation theory suggests that firms select markets in such a way that they seek to minimise perceived uncertainty. To accomplish this, firms would enter, regardless of their economic potential, markets in order to maintain and improve the relationship among their original clients.

3 In 1995, the Santander, BBV and Central Hispano banks had a foreign interest capital of 46.9 per cent, 26.4 per cent and 40.2 per cent respectively.

4 Such as, for example, the importance of the insurance market, the development of pension funds (driven by the reform of the Chilean social security system), the development of the capital market (a consequence of the privatization of large enterprises), etc.

5 Spanish savings banks (cajas de ahorros) were watching the growth of this market to the extent that they might be able to attend to a very particular sector, which is what characterises the savings bank (people with low purchasing power). The Valencia, Castellón and Alicante Savings Bank (BANCAJA) was, in the past, assessing the possibility of cooperating with BANORTE (the sixth ranking Mexican bank). In August 1998, CAJA MADRID (the second-ranking Spanish caja de ahorros) and MAPFRE (first-ranking insurance company) signed an agreement of alliance based on three insurance aspects: insurance in Spain; banking; and insurance in Latin America. MAPFRE entered this market in 1970 and is present in 15 of the region's countries.

6 Further details can be found in Camino et al. (1997) and Alvarez et al. (1999).
7 By "two-directional process of confidence", we mean that the financial entity goes where the industrial entity went, or, the other way round, the industrial firms will go, just because they know the financial entity will go too.

\section{References}

Aliber, R.Z. (1984), "International banking: a survey", Journal of Money, Credit and Banking, Vol. 16, pp. 661-78.

Alvarez, M.J., Cardone, C., Lado, N. and Samartín, M. (1999), Financial Service Firm's Entry-mode Choice, Network Linkages and Cultural Diversity: Spanish Company in Latin America, WP 99-70 (17), Business Economics Series, Universidad Carlos III de Madrid, Madrid.

Buckley, P.J., Pass C.L. and Prescott, K. (1991), "The internationalization of service firms: a comparison with the manufacturing sector", Scandinavian International Business Review, Vol. 1 No. 1, pp. 39-56.

Camino, D., Cardone, C. and Lado, N. (1997), "Foreign market entry decisions and distribution channels by Spanish insurers in Latin America: the MAPFRE experience", in Bock, L.C. (Ed.), Seminar Proceedings of the 33rd International Insurance Society Conference, "Strategies for Growth", pp. 209-33.

Cardone, C. and Cazorla, L. (1998), "The internationalisation process of Spanish banks: a tale of two times", Seminar Proceeding (CD) 24th Annual Conference of the European International Business Academy (EIBA), Israel. Cardone, C., Alvarez, M.J., Lado, N. and Sasi, V. (2000), "Going international: are financial service companies following manufacturing firms? The case of Finnish and Spanish banks and insurance companies”, CIBR Working Papers Z-8, Centre for International Business Research, Helsinki School of Economics and Business Administration.

Casson, M. (1990), "Evolution of multinational banks: a theoretical perspective", in Jones, G. (Ed.), Banks as Multinationals, Routledge, London.

CEPAL (2000), La Inversión Extranjera en América Latina y el Caribe (1999), Naciones Unidas, Santiago de Chile.

Chung, K.H. and Charoenwong, C. (1991), "Investment options, assets in place, and the risk of stocks", Financial Management, Vol. 20 No. 2, Autumn, pp. 21-33.

Czinkota, M.R. and Ronkainen, I.A. (1997), "International business and trade in the next decade: report from a Delphi study”, Journal of International Business Studies, Fourth Quarter, pp. 827-44.

Edvardsson, B. and Modell, S. (Eds) (1996), Service Management, Nerenius \& Santérus Förlag AB, Stockholm, pp. 7-13.

Enderwick, P. (1989), "Some economics of servicesector multinational enterprise”, in Enderwick (Ed.), Multinational Service Firms, Routledge, London. 
Engwall, L. and Wallenstål, M. (1988), “Tit for tat in small steps: the internationalisation of Swedish banks", Scandinavian Journal of Management, Vol. 4, pp. 147-55.

Erramilli, K. (1990), "Entry mode choice in service industries", International Marketing Review, Vol. 7 No. 5, pp. 50-62.

Erramilli, K. and Rao, C. (1990), "Choice of foreign market entry modes by services firms: role of market knowledge", Management International Review, Vol. 3 No. 3, pp. 135-50.

Giddy, I.H. (1986), "The theory and industrial organisation of international banking", in Gray (Ed.), Research in International Business and Finance, Volume 3, JAI Press, Greenwich, CT, pp. 195-243.

Goldberg, L.G. and Johnson, D. (1990), "The determinants of US banking activity abroad", Journal of International Money and Finance, Vol. 9, pp. 123-37.

Gray, J.M. and Gray, H.P. (1981), “The multinational bank: a financial MNC", Journal of Banking and Finance, Vol. 5, pp. 33-63.

Grubel, H.G. (1977), "A theory of multinational banking”, Banca Nazionale del Lavoro Quertely Review, December.

Heinkel, R.L. and Levi, M.D. (1992), "The structure of international banking”, Journal of International Money and Finance, Vol. 11, pp. 251-72.

Hellman, P. (1996), "The internationalisation of Finnish financial service companies", International Business Review, Vol. 5 No. 2, pp. 191-208.

Johanson, J. and Vahlne, J.E. (1977), “The internationalization process of a firm: a model of knowledge, development and increasing foreign market commitments", Journal of International Business, Vol. 8 No. 1, pp. 23-32.

Johanson, J. and Vahlne, J.E. (1990), "The mechanism of internationalization", International Marketing Review, Vol. 7 No. 4, pp. 11-24.

Johanson, J. and Wiedersheim-Paul, F. (1975), "The internationalization of the firm: four Swedish cases", Journal of Management Studies, Vol. 12 No. 3, pp. 11-24.

Jones, G. (1990), Banks as Multinationals Routledge, London and New York, NY.

Kester, W.C. (1993), Turning Growth Options into Real Assets, in AGGARWAL Capital Budgeting under Uncertainty, Prentice-Hall, Englewood Cliffs, NJ, pp. 187-207.

Lovelock, C.H. and Yip, G.S. (1996), "Developing global strategies for services business", California Management Review, Vol. 38 No. 2, pp. 64-86.

Luostarinen, R. (1970), "Foreign operations of firms", Helsinki School of Economics, Helsinki.

Luostarinen, R. (1979), "Internationalisation of the firm: an empirical study of the internationalisation of firms with small and open domestic markets with special emphasis on lateral rigidity as a behavioral characteristic in strategic decision making", Acta Academiae Oeconomiae Helsingiensis, Series A, p. 30.

McKinley Global Institute (1994).

Mahajan, A., Ragan, A. and Zardkoohi, A. (1996), "Cost structures in multinational and domestic banking”, Journal of Banking and Finance, Vol. 20, pp. 283-306.

Majkgård, A. and Sharma, D. (1998), "Clientfollowing and market-seeking strategies in the internationalization of serviced firms", Journal of Business-to-Business Marketing, Vol. 4 No. 3, pp. 1-41.

Mascareñas, J. (2000), "Las decisiones de inversión como opciones reales: un enfoque conceptual”, Documento de Trabajo UCM.

Myers, S.C. and Majd, S. (1990), "Abandonment value and project life", Advances in Futures and Options Research, Vol. 4, pp. 1-21.

Ruesgas, S.M. and Bichara, J.D. (1988), "Inversiones Españolas directas en América Latina en los años 90”, Boletín Económico del ICE, Vol. 2574, pp. 9-18.

Rugman, A.M. (1979), International Diversification and the Multinational Enterprise", Lexington Books, Boston, MA.

Rugman, A.M. (1981) Inside the Multinationals: The Economics of Internal Markets, Columbia University Press, New York, NY.

Salomon Smith Barney (1997), Bank Reference Guides of Argentina, Brazil, Chile, Colombia, Mexico, Peru and Venezuela, December.

Salomon Smith Barney (1998), Latin American Equity Research: Latin America - Banks, Latin American Bank Annual, May.

Sharma, D. and Johanson, J. (1987), "Technical consultancy in internationalisation", International Marketing Review, Vol. 4, pp. 20-9.

Terpstra, V. and Yu, C.M. (1988), "Determinants of foreign investment of US advertising agencies”, Journal of International Business, Vol. 19 No. 1, pp. 33-46.

Vandermerwe, S. and Chadwick, M. (1989), "The internationalization of services", The Service Industrial Journal, Vol. 9 No. 1.

Warner, A. (1998), "Latin fever catches on", The Banker, January, p. 66.

Wiedersheim-Paul, F. (1972), Uncertainty and Economic Distance: Studies in International Business, Uppsala.

Williams, B. (1997), "Positive theories of multinational banking: eclectic theory versus internationalisation theory", Journal of Economics Surveys, Vol. 11 No. 1, pp. 71-100.

World Development Report (1997), Transnational Corporations, Market Structure and Competition Policy, ONU.

World Investment Report (1996), Investment, Trade and International Policy Arrangements, ONU.

\section{Appendix}

Please see overleaf for Tables AI-AIII. 
$\overline{\text { Table Al }}$

Internationalisation process of Banco de Santander in Latin America

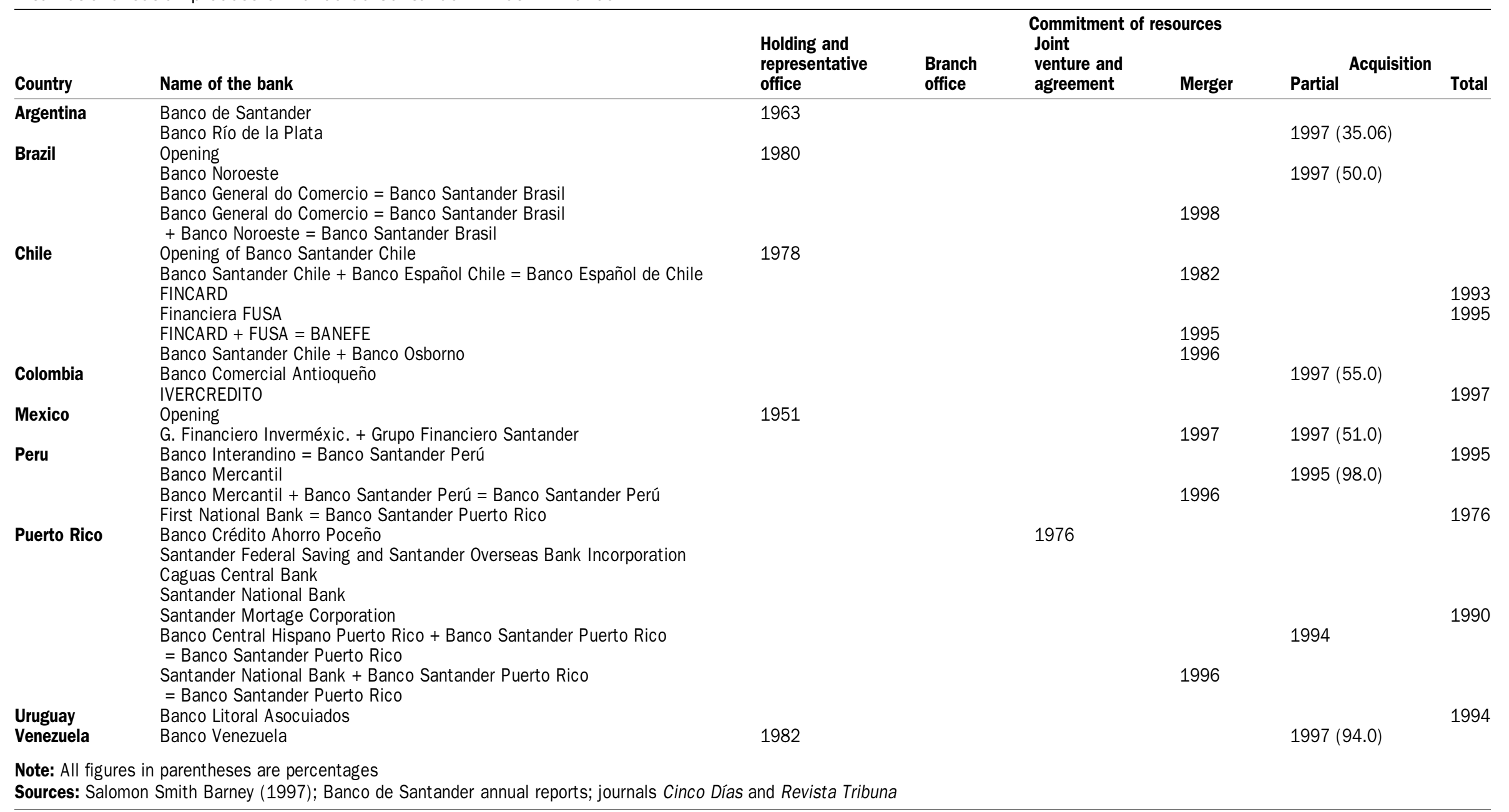




\section{Table All}

Internationalisation process of Banco Bilbao Vizcaya in Latin America

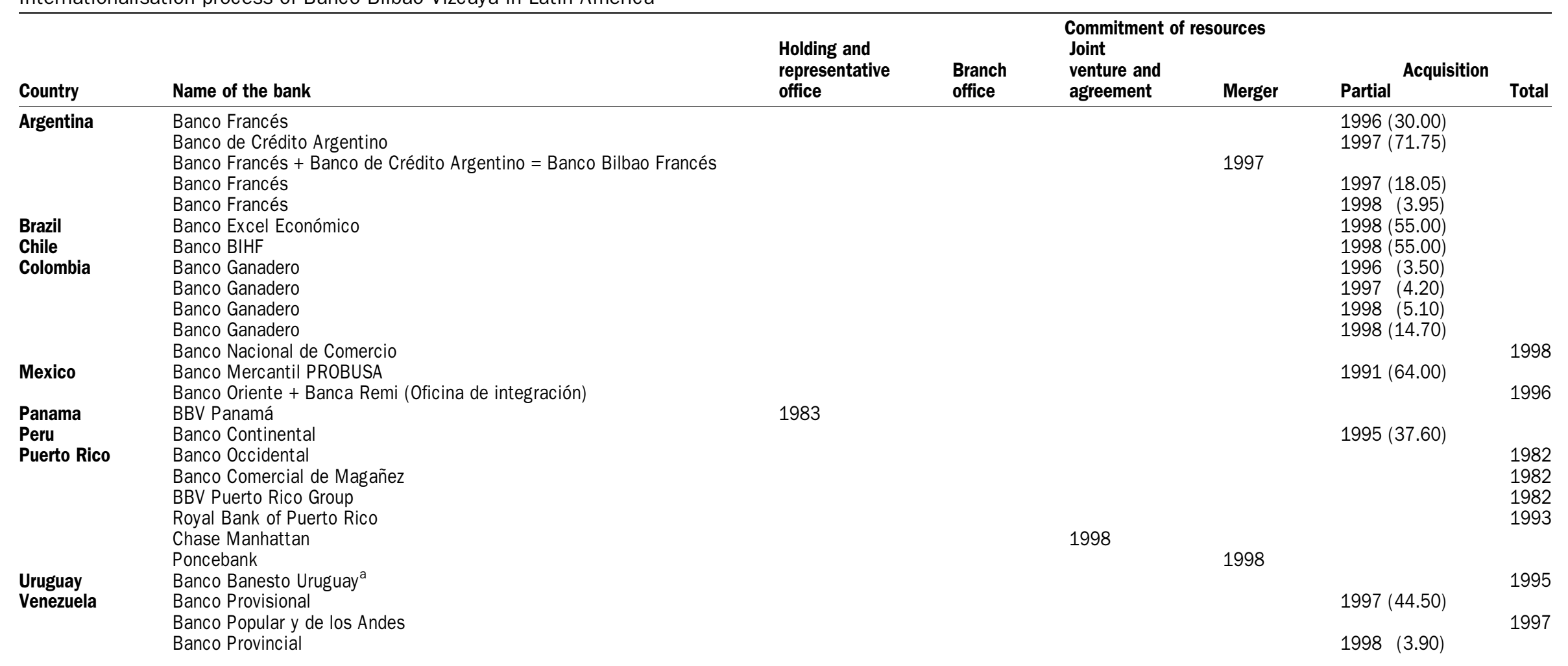

Notes: All figures in parentheses are percentages. ${ }^{a}$ Acquired by Banco Francés

Sources: Salomon Smith Barney (1997); BBV annual reports; journals Cinco Días and Revista Tribuna 


\section{$\overline{\text { Table AllI }}$}

Internationalisation process of Banco Central Hispano in Latin America

\begin{tabular}{|c|c|c|c|c|c|c|c|}
\hline Country & Name of the bank & $\begin{array}{l}\text { Holding and } \\
\text { representative } \\
\text { office }\end{array}$ & $\begin{array}{l}\text { Branch } \\
\text { office }\end{array}$ & $\begin{array}{l}\text { Commitment } \\
\text { Joint } \\
\text { venture and } \\
\text { agreement }\end{array}$ & ources & Partial Acquisition & Total \\
\hline Argentina & Banco Torquinst & 1973 & & & & & 1996 \\
\hline Brazil & Opening & 1973 & & & & 1993 (44.57) & \\
\hline Bolivia & Banco Santa Cruz de Bolivia & & & & & 1993 (90.00) & \\
\hline \multirow[t]{5}{*}{ Chile } & Holding O'Higgins Central Hispano ( $\mathrm{HOHCH})$ & 1988 & & & & 1993 (44.57) & \\
\hline & Inversiones Salto Grande & & & & & $1996(50.00)$ & \\
\hline & Banco O’Higgins & & & & & 1996 (38.93) & \\
\hline & Banco Santiago & & & & & $1996(25.40)$ & \\
\hline & Banco O'Higgings + Banco Santiago = Banco Santiago & & & & 1997 & & \\
\hline Colombia & Opening & 1973 & & & & & \\
\hline Costa Rica & Opening & 1973 & & & & & \\
\hline Dominican Republic & Opening & 1996 & & & & & \\
\hline Ecuador & Opening & 1990 & & & & & \\
\hline \multirow[t]{3}{*}{ Mexico } & Opening & 1973 & & & & & \\
\hline & Group PRIME internacional & & & & & 1993 (8.28) & \\
\hline & Group PRIME internacional (sold in 1996) & & & & & 1994 (8.28) & \\
\hline Panama & Opening & 1991 & & & & & \\
\hline \multirow[t]{2}{*}{ Paraguay } & Banco Asunción & & & & & $1994(77.76)$ & \\
\hline & Integration $\mathrm{OHCH}$ Holding & & & & & 1996 (38.88) & \\
\hline \multirow[t]{4}{*}{ Peru } & Opening & 1973 & & & & & 1994 \\
\hline & Banco del Sur & & & & & & \\
\hline & Banco del Libertador & & & & & & 1994 \\
\hline & Banco del Sur + Banco del Libertador = Bancosur & & & & 1996 & & \\
\hline \multirow[t]{2}{*}{ Puerto Rico } & Banco Central Hispano Puerto Rico (sold in 1996) & & & & & $1994(99.22)$ & \\
\hline & Banco Central Hispano Internacional & & & & & $1995(0.03)$ & \\
\hline \multirow[t]{2}{*}{ Uruguay } & Central Hispano Uruguay & 1991 & & & & & 1995 \\
\hline & Integration OHCH EUROBANCO (1998) (sold in 1997) & & & & & & 1996 \\
\hline Venezuela & & 1973 & & & & & \\
\hline $\begin{array}{l}\text { Note: All figures in } p \\
\text { Sources: Salomon } \mathrm{Sn}\end{array}$ & $\begin{array}{l}\text { ses are percentages } \\
\text { ney (1997); BCH annual reports; journals Cinco Días an }\end{array}$ & Tribuna & & & & & \\
\hline
\end{tabular}

